\title{
Falta de Notificação em Multa de Trânsito e Licenciamento
}

\author{
Euripedes G. Faim $\mathscr{F}^{Q^{t}}$ \\ Artur M. de Oliveira gr.
}

INTRODUÇÃO

$$
\text { N. }
$$

L dia a dia forense tem sido comum
surgirem processos onde se questiona o cabimento da negativa de licenciamento de veículo por existência de multas não pagas, normalmente sendo alegado falta de notificação com relação a essas.

Tal problema se avolumou muito após o novo Código de Trânsito Nacional que possibilitou aos municípios a aplicação de multas e as tornou bem mais onerosas que antes.

Hoje tem-se como pacífico que são ilegais as multas aplicadas sem notificação do suposto infrator no prazo legal.

Tal regra é expressa no Código Nacional de Trânsito que dispõe:

“[...] Art. 281 - A autoridade de trânsito, na esfera da competência estabelecida neste Código e dentro de sua circunscrição, julgará a consistência do auto de infração e aplicará a penalidade cabível.
Parágrafo único - $O$ auto de infração será arquivado e seu registro julgado insubsistente: [...]

II - se, no prazo máximo de trinta dias, não for expedida a notificação da autuação. [...]"

Esse dispositivo é fruto do princípio constitucional consagrado no art. $5^{\circ}, \mathrm{LV}$, da Constituição Federal:

"aos litigantes, em processo judicial ou administrativo, e aos acusados em geral são assegurados o contraditório e ampla defesa, com os meios e recursos a ela inerentes." (grifo nosso)

Da mesma forma, isso baseia-se no principio do Direito Administrativo de que o poder de polícia, no caso polícia de trânsito, só pode ser exercido de forma regular, ou seja, deve ser desempenhado pelo órgão competente, nos limites da lei aplicável, com observância do processo legal e, tratando-se de atividade que a lei tenha como discricionária, sem abuso ou desvio

1 Eurípedes Gomes Faim Filho é Juiz de Direito em São Vicente, Estado de São Paulo, Mestre em Direito pela USP, professor da Faculdade de Direito da UNIMONTE, ex-professor da Faculdade de Direito da UNESP, ITE e UNOESTE.

Artur Martinho de Oliveira Júnior é Juiz de Direito em São Vicente, Estado de São Paulo. 
de poder. ${ }^{2}$

tente para o mesmo.

Em razão dessas regras a jurisprudência tem sistematicamente acolhido as alegações de impossibilidade de negação de licenciamento nesses casos, o que até foi objeto da súmula 127 do E. Superior Tribunal de Justiça:

"É ilegal condicionar a renovação da licença de veículo ao pagamento de multa, da qual o infrator não foi notificado."

Tal também tem sido o entendimento da melhor doutrina:

"[ ... ] em caso de multa, deverá estar consolidada ou decidida, com a prévia notificação do devedor e a possibilidade dos meios de defesa. Tendo havido apenas a lavratura do auto de infração, sem a posterior homologaçâo pela autoridade competente, não se torna exigivel a multa. Considerando que o licenciamento é condição para o veículo circular, não se admite a negativa em fornecer o certificado, se atingida a época da respectiva renovação, e não obedecidas as formalidades para firmar a exigibilidade da cominação. Arbitrária a atitude em condicionar a licença ao pagamento, se a notificação ocorre no momento em que se providencia aquela. [ ... ]"3 (grifo nosso)

No entanto, dúvidas têm surgido a respeito de qual seria a autoridade coatora contra quem o pretendente ao licenciamento deveria se insurgir, bem como quanto ao meio processual cabível e à autoridade judiciária compe-

Este estudo pretende oferecer subsídios para a solução desses problemas, razão pela qual, num primeiro momento, questionaremos o ato administrativo da negativa do licenciamento, em seguida discutiremos a existência de litisconsórcio entre autoridades administrativas, a competência do juízo e a forma de se pleitear e julgar pedidos de liminares.

\section{O ATO ADMINISTRATIVO DENE GATÓRIO DO LICENCIAMENTO}

A autoridade administrativa que tem atribuição para deferir o licenciamento é o delegado de polícia de trânsito do município onde se encontra registrado o veículo.

Tal regra encontra-se no Código de Trânsito Brasileiro em seu artigo 130:

"Todo veículo automotor, elétrico, articula do, reboque ou semi-reboque, para transitar na via, deverá ser licenciado anualmente pelo órgão executivo de trânsito do Estado, ou do Distrito Federal, onde estiver registrado o veículo." (grifo nosso)

Logo, como essa é a autoridade que tem atribuição para realizar o licenciamento, também é ela a autoridade que tem poderes para denegá-lo devido à existência de multas, assim, ela é a autoridade coatora no caso.

No Estado de São Paulo criou-se a pos-

2 Tais regras que valem para todo o Direito Administrativo estão previstas no Código Tributário Nacional no seu art. 78, parágrafo único: "Considera-se regular o exercício do poder de polícia quando desempenhado pelo órgão competente nos limites da lei aplicável, com observância do processo legal e, tratando-se de atividade que a lei tenha como discricionária, sem abuso ou desvio de poder."

3 RIZZARDO, Amnaldo. Comentários ao Código de Trânsito Brasileiro. São Paulo: Revista dos Tribunais, 1998, pág. 393.

Revista da Faculdade de Direito da UFRGS, v. 19, Março/2001 sibilidade de se realizar o licenciamento eletrônico disponível nas instituiçōes bancárias conveniadas. ${ }^{4}$ Tal atitude é digna de todo louvor, no entanto não altera em nada o fato de que a autoridade designada pela lei continua a mesma.

Não tem relevância o fato de que, pelo sistema de "autenticação digital", criado por essas portarias, as taxas, IPVA, multas de trânsito e ambientais, assim como os demais encargos que possam recair sobre os veículos, devam ser pagos em instituições bancárias, que, a partir da data da portaria, estão interligadas à PRODESP e são responsáveis pela prévia pesquisa de tais débitos.

Bem assim, carece de importância igualmente poder o licenciamento ser feito nessas instituições, mediante pagamento das multas e encargos, e depois recebido em casa pelo interessado por via postal.

E tal se dá, basicamente, por três razões:

Primeiro, portarias não têm o condão de revogar a lei, assim não podem alterar competência administrativa instituída pelo Código de Trânsito.

Segundo, porque o licenciamento previsto pelo sistema dessas portarias só terá utilidade para o caso de o proprietário do veículo concordar com as multas e encargos exigidos e pagá-los. Caso haja divergência, o proprietário só pode requerer o licenciamento à autoridade legalmente competente, ou seja, ao delegado da CIRETRAN do município em que o veículo estiver registrado.

Terceiro e último, porque a própria portaria CAT/DETRAN 001 em seus artigos $4^{\circ}, 5^{\circ} \mathrm{e}$ $16, \S 2^{\circ}$, devido a várias exceções à permissão de licenciamento eletrônico, prevê que os problemas que surgirem sejam solucionados " $p e$ rante a unidade de trânsito do registro do veículo" (art. 16, § 2o $)^{5}$

Saliente-se que isso não poderia ser de forma diversa, pois basta que haja uma multa,

4 Portaria 316 de 22 de março de 2000 do Delegado de Polícia Diretor do Departamento Estadual de Trânsito e Portaria CATDETRANn 001 , de 22 de março de 2000 do Coordenador da Coordenadoria da AdminisPPoro Thbutara da Secretoria de Bstado tração Thibutra da Sereara de Estado dos Negónos da Fazida e do delegado de Pollcia Diretor do Departamento Estadual de Trânsito da Secretaria de Estado da Segurança Pública, todos do Estado de São Paulo.

5 Portaria CATDETRAN 001: "[...] Artigo $4^{\circ}$ - O serviço requerido perante a unidade de trânsito obrigará o interessado a apresentar o comprovante de pagamento bancário, bem como os demais documentos digitar o conjunto de caracteres alfanuméricos inseridos naquele documento, como condição obrigatória para o reconhecimento, validação e posterior emissão dos certificados de registro ou de licenciamento.

Artigo $5^{\circ}$ - A existência de multas aplicadas pelos órgãos executivos munici pais de trânsito, não conveniados com o Governo do Estado de São Paulo, implicará na inserção no comprovante de pagamento bancário da mensagem "existem débitos munici pais", obrigando o usuário a procurar o órgão competente para regularização e desbloqueio da restrição contida no banco de dados do Departamento Estadual de Trânsito, condição necessária e indispensável para a posterior emissão do certificado de registro ou de licenciamento. [...]

Artigo 16, [... $\S 2^{\mathrm{o}}$ : A realização do serviço perante a unidade de trânsito de registro do veículo, implicará na obrigacão de o interessado apresentar o comprovante de pagamento bancário, bem como os demais documentos estabelecidos pelo Departamento Estadual de Trânsito, contendo necessariamente a autenticação digital, nos termos do contido no art. $4^{0}$ desta Portaria. [... " (grifo nosso)

Revista da Faculdade de Direito da UFRGS, v. 19, Marco/2001 
legal ou não, para que seja obrigatório assegurar ao proprietário do veículo o direito à ampla defesa com os meios e recursos a ela inerentes, isso não podendo ser relegado, sob pena de não ser regular o exercício do poder de polícia por inobservância do devido processo legal.

$\mathrm{E}$ tal ato denegatório do licenciamento só pode ser considerado legal se baseado em multas legais, pois, caso contrário, o vício de ilegalidade das multas contaminaria esse ato, pois não há ato legal baseado em ato ilegal. ${ }^{6}$

Ocorre que esse ato administrativo da denegação do licenciamento merece uma análise mais profunda para definir-se realmente quem é a autoridade coatora.

Sobre isso manifestou-se o Tribunal de Justiça do Estado de São Paulo em mandado de segurança:

“[... JMULTA DE TRÂNSITO-São Vicente Licenciamento de veículo - Súmula STJ127 - 1. Não pode o Diretor de Trânsito, em havendo multas pendentes, permitir o licenciamento do veículo, nem demonstrar a regularidade de autuação e multa que outra autoridade, não ele, procedeu. Não pratica ele, à primeira vista, ilegalidade nem tem o infrator direito ao licenciamento nessa hipótese. Ato complexo que exige a presença da autoridade que efetuou a autuação. - 2. O fundamento do pedido - falta de notificação - exige se traga ao pólo passivo a autoridade municipal ou estadual que efetuou a autuação, é responsável pela imposição da penalidade e por sua regularidade formal. Sem sua presença não se tem demonstrado a liquidez nem a certeza do direito. Re curso de oficio a que se dá provimento para

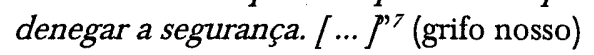

Concordamos com esse acórdão quando diz que é necessária a presença no pólo passivo do mandado de segurança da autoridade que efetuou a autuação, mas não que se trata de ato complexo.

Os atos administrativos são classificado pela doutrina, quanto à formação da vontade, em simples, complexos e compostos.

Simples são os atos que advém da manifestação de vontade de apenas um órgão, singular ou colegiado, por exemplo, licença para porte de arma. $^{8}$

Complexos são os que decorrem da declaração de vontade de dois ou mais órgãos, independentemente de serem singulares ou colegiados. Hely Lopes MeIRELles exemplifica com a investidura de um funcionário na qual a nomeação é feita pelo Chefe do Executivo e a posse e exercício é dada pelo chefe da repartição em que vai servir o nomeado. ${ }^{9}$
6 Nesse sentido Apelação com revisão no $10558.5-00$. Tribunal de Justiça do Estado de São Paulo. Relator o E. Desembargador Brenno Marcondes. Julgamento realizado no dia 09 de dezembro de 1999. No corpo do E. Desembarg:

"[...] Quanto a preliminar argüida pela Fazenda do Estado, também é ela rejeitada, pois o Delegado Titular da $16^{\mathrm{a}}$ Ciretran tinha poderes para deliberar sobre a questão do licenciamento e para delibera outros atos colocados sob a sua égide. É sabido que as determinaçôes superiores devem ser cumpridas fielmente, salvo se ilegais [...]"(grifo nosso)

7 Apelação n ${ }^{\circ} 101.544 .5 / 7$ da $8^{a}$ Câmara de Direito Público do Tribunal de Justiça do Estado de São Paulo. Relator O E. Desembargador TORRES DE CARVALHO. Data do julgamento: 26 de janeiro de 2000

s BASTOS, Celso Ribeiro. Curso de Direito Administrativo. $3^{\underline{a}}$ edição. São Paulo: Saraiva, 1999, pág. 112.

9 Direito Administrativo Brasileiro. $21^{\text {a }}$ edicão atualizada por EURICO DE ANDRADE AZEVEDO, DELCIO BALESTRO AleEXo e Jose EMMANUEL BURLE FLHO. São Paulo: Malheiros, 1996, pág. 154.

Revista da Faculdade de Direito da UFRGS, v. 19, Março/2001
Por fim, composto é aquele ato que se origina da vontade de dois ou mais órgãos, no qual, na expressão de Di PIETRO, "a vontade de um é instrumental em relação a de outro, que edita o ato principal." Esclarece essa professora que no ato complexo há uma fusão de vontades para a prática de um único ato, enquanto que no ato composto há dois atos, sendo um princi pal e o outro acessório que pode ser pressuposto ou complementar do principal. Essa autora exemplifica com a nomeação do Procurador Geral da República na qual a nomeação que é o ato principal, depende de aprovação prévia do Senado, que é o ato acessório pressuposto do princi pal. ${ }^{10}$

$\mathrm{O}$ ato denegatório do licenciamento, nosso ver, não é um ato complexo, pois no caso não há uma fusão de vontades na prática de um único ato.

Tampouco trata-se de ato composto po que não há uma relação de instrumentalidad ou complementação entre tal ato e a multa anteriormente imposta.

Também não se trata de ato completamente simples, pois não se pode negar a influência de uma vontade de outro órgão, aquele que impõe a multa, na decisão de denegação do licenciamento.

Para nós o caso é de atos correlatos no ensinamento do Desembargador CARLOS ORTTZ

"MANDADO DE SEGURANCA Serventia de Justiça - Concurso - Procedimento para provimento - Ato administrativo complexo que ensejaria impetração simultânea contra todas as autoridades envolvi-

das - Descabimento - Atos sucessivos porém autônomos entre si - Carência decretada - Processo extinto sem julgamento do mérito. $O$ ato administrativo comple $x o$ é aquele que se apresenta incompleto em sua formação, dependendo ainda de um ato complementar para tornar-se operante. Quando cada ato produz efeitos jurídicos, inclusive o de administrativamente propiciar outros atos, não há que se falar em complexidade e, sim, em correlação." ${ }^{\prime \prime}$ (grifo nosso)

No caso, a multa e a denegação do licenciamento são atos autônomos, sendo que a multa produz o efeito jurídico de ensejar o to de denegação, de onde se conclui que há correlação.

Assim, como a legalidade ou não da denegacão do licenciamento está totalmente relacionada com a legalidade ou não da multa concluímos que não é possível julgar-se incabível a denegação do licenciamento sem antes fazer isso com relação à multa, mesmo que apenas se trate de uma decisão incidental.

Dessa forma, no caso de um mandado de segurança, por exemplo, a impetração apenas contra o delegado que nega o licenciamento não é possível, devendo integrar a lide a autoridade que aplicou a multa, pois há a litisconsórcio.

Não se diga que o delegado não é parte legitima por não lhe ser possível controlar regularidade das autuações.

Tal entendimento se basearia no seguin te ensinamento de HELY LOPES MEIRELLES:

10 DI PIETRO, Maria Sylvia Z.. Direito Administrativo. 11 $1^{a}$ edição. São Paulo: Atlas, 1999, pág. 207.

II Tribunal de Justiça do Estado de São Paulo. Relator o E. Desembargador CARLOS ORTIZ - Mandado de Segurança n. 14.743-0. Data do julgamento: 17 de fevereiro de 1993. 
"[...] Incabível é a segurança contra autoridade que não disponha de competência para corrigir a ilegalidade impugnada. A impetraçẫo deverá sempre ser dirigida contra a autoridade que tenha poderes $e$ meios para praticar o ato ordenado pelo Judiciário. [...]" 12 (grifo nosso)

Quando o pedido versar exclusivamente sobre o licenciamento, a autoridade com atribuições para praticá-lo é o delegado responsável pelo trânsito que, assim, é parte legítima, mas não só ele, como supra.

Assim, entendemos haver um litisconsórcio no caso, cabendo-nos agora questionar que tipo de litisconsórcio seria e qual o juízo competente, o que faremos no próximo item deste artigo.

\section{DA NECESSIDADE DO LITISCON- SÓRCIO PASSIVO}

2.1. Da noção de litisconsórcio

O presente estudo deve partir da noção do que seja litisconsórcio.

Da lição de Arruda e Thereza Alvim podemos concluir que $o$ instituto do itisconsórcio consiste no fenômeno de se ter, num dos pólos da relação processual, ou em ambos, uma pluralidade de autores e, ou, réus. ${ }^{13}$
Os litisconsórcios podem se classificar de acordo com: a) o momento de sua formação em inicial e ulterior; b) a obrigatoriedade ou tivo; c) a sorte no plano de direito material, em simples e unitário; d) a posição subjetiva, em ativo, passivo ou misto.

Em vista do objetivo deste estudo, bem como em virtude das demais serem intuitivas, abordaremos apenas as classificações quanto à obrigatoriedade ou não da formação do litisconsórcio e quanto à sorte no plano de direito material.

Quanto à sua obrigatoriedade o litisconsórcio poderá ser facultativo ou necessário.

Será facultativo quando sua formação dependa exclusivamente da vontade das partes envolvidas, como ocorre, por exemplo, quando um condômino reivindica a coisa comum em poder de terceiro (art. 623, II, do Código Civil). A reivindicação pode ser feita, facultativamente, por apenas um, mais de um ou por todos os condôminos, sem que, com isso, haja qualquer transgressão da lei ou prejuízo da relação jurídica havida entre aquele ou aqueles que são donos da coisa comum e o terceiro que injustamente a detém.

De outro lado, será necessário quando a sua formação seja determinada por lei ou pela

12 Mandado de Segurança, Ação Popular, Ação Civil Pública, Mandado de Injunção, Habeas Data. $18^{a}$ edição São Paulo: Malheiros, 1997, pág. 54.

13 No dizer desses mestres: "[.../normalmente, há nos processos, um autor litigando contra um réu, disputando sobre uma única lide ou objeto litigioso, a respeito da qual existem questões, sejam de fato ou de direito, ou de ambas as espécies. Poderá haver um autor contra um réu e mais de uma lide (v. art. 292), para o que há um regime e obediência a requisitos especiais. Pode haver também mais de um autor (litisconsórcio ativo), ou, então, um autor contra vários réus (litisconsórcio passivo), ou, ainda haver vários autores contra vários réus (litisconsórcio misto); neste fenômeno consiste o instituto do litisconsórcio, cuja característica marcante é a existência de pluralidade de partes, num mesmo pólo, ou em ambos os pólos do processo. [..." (Assistência - Litisconsórcio, Repertório de Jurisprudência e Doutrina. São Paulo: RT, 1986, pág. O1).

Revista da Faculdade de Direito da UFRGS, v. 19, Março/2001

natureza da relação jurídica que envolve as partes litigantes, de tal modo que, sem sua existência a sentença a ser proferida não terá plena eficá cia na solução da lide. Esse conceito é facilmente extraído da melhor doutrina, ensinada pelos mestres Arruda e Thereza Alvim, JosE Frederico Marques e Humberto Theodoro JÚNIOR. ${ }^{14}$

Quanto à sorte no plano do direito material, ou seja, quanto ao resultado da ação podemos diferenciar o litisconsórcio em unitário e simples.

Na ausência de definição legal, devemo nos socorrer das lições dos grandes doutrinadore para obtermos o conceito preciso dessas espécies de litisconsórcios.

De sua lição podemos concluir que ocorre litisconsórcio unitário quando todos os litisconsortes que figurem no mesmo pólo da relação processual devam ter a mesma sorte na solução da lide proposta. Assim, não é possível que um dos litisconsortes sagre-se vencedor e os demais vencidos. Ou todos vencem a demanda ou todos são vencidos. ${ }^{15}$

Ao contrário, no litisconsórcio simples, é possível que a ação seja favorável para alguns dos consortes e desfavorável para outros.

Sintetizando, se para a eficácia da sentença é indispensável a presença num dos pólos, ou em ambos, de mais de um autor ou de mais de um réu, o litisconsórcio é necessário (e não facultativo) e, se todos os autores ou todos os réus, da relação jurídico-processual, devem ter a mesma sorte na solução da lide, o litisconsórcio é unitário (e não simples).

Após relembrarmos esses conceitos, estamos aptos a definir a existência ou não de litisconsórcio no caso dos pedidos, via manda-

14 Assim, conforme ensinamento de ARRUDA e THEREZA ALVM, "[...] no litisconsórcio necessário, é indispensável a presença conjunta de diversos autores ou diversos réus, sob pena de ineficácia da sentença; no litisconsórcio facultativo, pode o litisconsórcio ser formado ou não, nada afetando sua não formação, os efeitos da sentença, que, todavia, atingirão somente quem tenha sido parte (art $472,1^{\text {a }}$ frase) Noliticonsócio tem relevância, na formação do litisconsórcio facultativo, sendo-lhe imposto pela vontade do autor, desde que a lei o permita (art. 46). É irrelevante, também, a vontade do juiz, que não pode impor a formação do litisconsórcio facultativo. [..." (Op. cit., pág. 02.)

No mesmo sentido MARQUES, José Frederico. Manual de Direito Processual Civil. $I^{\prime}$ edição. São Paulo: Saraiva, 1982, Vol. I, pág. 272-273

Já HUMBERTO THEODORO JÚNIOR, após criticar a definição legal constante do art. 47 do CPC, "...J pois o Código definiu o litisconsórcio necessário conforme apenas as características do litisconsórcio unitário", afirmou que "....] podemos concluir que litisconsórcio necessário, ativo ou passivo, é aquele sem cuja observância não será eficaz a sentença, seja por exigência da própria lei seja pela natureza jurídica litigiosa. (...)" Curso de Direito Processual Civil. g' Ediçāo. Rio de Janeiro: Forense, 1992, Vol. I, pág. 109.)

15 Para ARRUDA e THEREZA ALVIM, "[...] tendo em vista a identidade, relativamente à sorte no plano do direito material, da decisão em que figurarem litisconsortes, podemos classificá-los em simples ou unitário. Será unitário o litisconsórcio quando a demanda deva ser decidida de forma idêntica para todos quantos figurem em um mesmo pólo da relação processual. A normalidade do funcionamento da atividade jurisdicional, no litisconsórcio unitário é a de que, realmente, todos os litisconsortes unitários, situados em um dos pólos do processo, tenham sorte efetivamente idêntica, no plano do direito material. [..."

“[... Será simples o litisconsórcio quando tal identidade não tiver necessariamente de ocorrer, nem no plano processual, nem no material. [...p" (Op. cit., pág. 02)

Revista da Faculdade de Direito da UFRGS, v. 19, Marfo/2001 
do de segurança, de licenciamento de veículo automotores sem o prévio pagamento das multas de trânsito pendentes e da respectiva anulação ou declaração de insubsistência dessas pe nalidades. Tratamos mais do mandado de segurança por ser a via mais comum.

\subsection{O litisconsórcio no caso em estudo}

De início, cumpre-nos destacar que, quer $o$ impetrante peça apenas o licenciamento do veículo ou, além dele, também a declaração de nulidade ou insubsistência das multas, a relação jurídico-processual exigirá a formação do litisconsórcio passivo, que será, pois, necessário Note-se que, pleiteando o impetrante licenciamento e a declaração de nulidade da multas, uma vez que o primeiro só foi proibido pelo delegado de trânsito em virtude da existência das multas impostas pela autoridade competente, não há como se deixar de formar o litisconsórcio, porque o licenciamento é ato de atribuição do delegado e à outra autoridade de trânsito deve ser assegurada a oportunidade $d$ apresentar a prova da notificação e da existência de regular procedimento administrativo anterior à imposição da multa, sob pena de, a sim, o próprio Poder Judiciário negar vigênci ao princípio constitucional do devido processo legal, especialmente com afronta ao contraditó rio e à ampla defesa.

Questão interessante, mas não de solução diferente, surge quando o pedido formulado no "mandamus" é exclusivamente de licenciamento.

O licenciamento é de atribuição exclusiva do delegado de trânsito, todavia, como o fundamento utilizado, como regra, nas impetrações, é o da ausência das notificações (arts. 281 e 282, Código de Trânsito Brasileiro (CTB), com conseqüente quebra da ampla defesa, no procedimento administrativo da imposição da multa, sendo essa a causa da proibição do licenciamento, a correlação dos atos simples praticados pelas autoridades envolvidas cria relação jurídica indissolúvel entre elas, a impor, de igual forma, a formação do litisconsórcio que é, portanto, necessário.

Afinal, a sentença a ser proferida no mandado de segurança não será eficaz contra o delegado de trânsito, sem que se dê à autoridade que impôs a multa a possibilidade de demonstrar a validade da sanção aplicada e tal só será possível se essa autoridade puder defender seu ato, o que só ocorrerá se for citada, ou notificada, para prestar suas informações.

Inafastável, também nesse caso, o litisconsórcio necessário.

Nesse sentido, recentemente, a egrégia 8a Câmara de Direito Público do Tribunal de Justiça de São Paulo já decidiu que o Diretor de Trânsito não pode responder sozinho a mandado de segurança em que se pleiteia o licenciamento, pois, a natureza do ato "[...] exige a presença da autoridade que efetuou a autuação [...]", uma vez que "[...] o fundamento do pedido - falta de notificação - exige se traga ao pólo passivo a autoridade municipal ou estadual que efetuou a autuação, (que) é responsável pela imposição da penalidade e por sua regularidade formal. Sem sua presença não se tem demonstrado a liquidez nem a certeza do direito.

S Supremo Tribunal Federal também já decidiu que: $[\ldots]^{16}$ (grifo nosso)
"Se a sentença a ser proferida em mandado de segurança é suscetível de afetar possível direito subjetivo oriundo do ato impugnado, em favor de terceiros, estará caracte rizado o litisconsórcio necessário." (grifo nosso)

Por isso, entendemos que a natureza da relação jurídica exige a formação do litisconsórcio, sob pena de não se assegurar ao Estado, no processo judicial, o mesmo de que reclama o impetrante da esfera administrativa ou seja, o direito ao contraditório e à ampla defesa, e, assim, somos de opinião de que esse litisconsórcio é necessário. tário?

Além de necessário, seria também uniPensamos que não.

Analisando o caso do mandado de segurança visar ao licenciamento ou, esse e mai a declaração de nulidade das multas impugnadas, os litisconsortes poderiam ter a mesma sort na solução da demanda, na medida em que, se as multas impostas tivessem atendido aos critérlicenciamento sem o prévio pagamento seria do mesmo jeito, legal.

Desse modo, a sorte da sentença seria gual, idêntica, para o delegado de trânsito para a autoridade que impôs a multa. Mas essa idéia só valeria para o caso de ser apenas uma autoridade responsável pela lavratura de uma única multa exigida pelo delegado de trânsito para o licenciamento. Caso contrário, havendo mais de uma autoridade autuante ou mais de uma multa não seria mais possível assegurar unitariedade.

Poderia haver, por exemplo, uma ou os legais para sua aplicação, a proibição do algumas multas válidas da mesma autoridade responsável pela lavratura, enquanto outras nulas, isso levaria ao reconhecimento de nulidade de algumas e não de outras, e daí o ato denegatório do licenciamento poderia ser lesivo ao direito do impetrante apenas com relação à exigência das multas ilegais e não das demais.

A unitariedade ocorreria, ainda, se todas as multas fossem viciadas, pois a proibição do licenciamento seria lesiva a direito líquido e certo do proprietário do veículo que não poderia ter a renovação de licença de trânsito vedada sem a existência de multa válida que a impeça, nos termos do art. 131, $\S 2^{\circ}$, do Código de Trânsito Brasileiro. Ou, se todas as multas fossem válidas, posto que o proibição do licenciamento seria absolutamente legal, sem qualquer lesão ou ameaça a direito do impetrante.

Assim, como o mais comum nas lides forenses é a ocorrência de irresignação contra várias multas emanadas de diversas autoridades munici pais, estaduais e federais de trânsito, devemos concluir que o litisconsórcio em questão é simples, admitindo a procedência parcial da ação, inclusive podendo atribuir sortes diferentes para as autoridades que figurem no pólo passivo da causa.

2.3. Ausência de notificação de litisconsorte, conseqüência.

Nesse ponto, convém iniciarmos com 0 disposto no art. 19 da Lei do Mandado de Segurança (LMS), Lei $\mathrm{n}^{\circ}$ 1.533/51, que manda aplicar, em caso de litisconsórcio, o que previsto sobre o tema no Código de Processo Civil. No Estatuto Processual, merece destaque o 47 e seu parágrafo único, cujo conteúdo determi-
16 Tribunal de Justiça do Estado de São Paulo. Apelação n. 101.544.5/7. Relator o E. Desembargador ToRRES DE CARVALHO. Julgamento realizado no dia 26 de janeiro de 2000.

Revista da Faculdade de Direito da UFRGS, v. 19, Março/200

17 Supremo Tribunal Federal, $2^{a}$ Turma, RE 87.094-DF, julgamento realizado no dia 03 de junho de 1977. Relator o E. Ministro DJACI FALCAO. DJU 1.7.77, p. 4.466, v.u.

Revista da Faculdade de Direito da UFRGS, v. 19, Março/2001 
na que, havendo litisconsórcio necessário, o Juiz deve ordenar que a citação, ou, no caso do "writ of mandamus", que a notificação, realize-se no prazo que assinar, sob pena de declarar extinto o processo.

Essa providência deve ser determinada de imediato, de preferência no despacho inicial, mas, pelo menos, antes da sentença. Embora respeitando as ponderáveis opiniões em contrário, baseadas na especialidade do rito, entendemos que oJuiz, ao verificar que a inicial do mandado de segurança não atende às exigências legais, quer em face do litisconsórcio (v. art. 19, LMS), quer por falta de algum requisito dos arts. 282 e 283 , do Código de Processo Civil, deve determinar a emenda, com as correções necessárias. MEIRELLES:

Nesse sentido a lição de HeLY LOPES

"Pela nova sistemática do Código de Processo Civil, o Juiz deverá, primeiro, mandar suprir as falhas da inicial, no prazo de dez dias, e só após a omissão da parte é que proferirá o despacho indeferitório (CPC, art. 284, parágrafo único). Essa oportunidade de correção da inicial se nos antolha de inteira aplicação ao procedimento do mandado de segurança, para economia e celeridade processuais na impetração." ${ }^{\prime 8}$

\section{E se a notificação não ocorrer?}

A jurisprudência aponta que o resultado será a nulidade do processo.
Nesse sentido:

"Verificando o tribunal do segundo grau de jurisdição a falta de citação dos litisconsortes passivos necessários, deve anular o feito e determinar que $o$ juiz singular cumpra o disposto no art. 47, par. único, do $C P C^{\prime \prime g}$ (grifo nosso)

"Se a sentença a ser proferida em mandado de segurança é suscetível de afetar possivel direito subjetivo oriundo do ato impugnado, em favor de tercei ros, estará caracterizado o litisconsórcio necessário. Se não forem es ses terceiros convocados para integrar a lide, como parte passiva, positiva-se a negativa de vigência do art. 19 da lei do mandado de segurança e do art. 47 do CPC. Pela natureza da relação jurídica, o juiz tem de decidir a lide de modo uniforme para todas as partes, abrangendo, assim, as pessoas que foram benef ciadas pelo ato impugnado ${ }^{20}$ (grifo nosso)

"Verificada a existência do litisconsórcio passivo necessário, julgado o mandado de segurança sem que tenha sido citado o litisconsorte para integrar a lide, opera-se a nulidade da sentença. Toda vez que o mandado de segurança implicar modificação da posição jurídica de outras pessoas, que foram diretamente beneficiadas pelo ato impugnado, ou mais precisamente, quando a sentenca modificar o direito subjetivo criado pelo ato impugnado em favor de

18 Mandado de Segurança. 19å edição. São Paulo: Malheiros, 1998, pág. 67

19 E. Superior Tribunal de Justiça. $4^{\underline{a}}$ Turma. Resp. 28.559-1-SP. Relator o E. Ministro TORREAO BRAZ. Julgamento realizado no dia 13 de dezembro de 1994, deram provimento, v.u., DJU 20.3.95, p. 6.120, $2^{3}$ col. em.

20 Supremo Tribunal Federal. $2^{2}$ Turma. RE 87.094-DF. Julgamento realizado no dia 3 de junho de 1977. Relator o E. Ministro DJACI FALCÄO, DJU 1.7.77, p. 4.466, v.u.

Revista da Faculdade de Direito da UFRGS, v. 19, Março/2001 outras pessoas, haverá litisconsórcio necessário, e a sentença não poderá ser dada sem que esses terceiros sejam citados como partes passivas na ação. Se o impetrante não houver pedido a citação, poderá o Juiz determiná-la, na forma do art. 47, parágrafo único, do $C P C .{ }^{21}$ (grifo nosso)

A aplicação do art. 19 da LMS e do art. 47 do CPC ao caso do litisconsórcio necessário do mandado de segurança do licenciamento de veículos tem reflexo direto sobre a competência, o que passamos a analisar.

3. REGRA GERAL DA COMPETÊN CIA EM MANDADO DE SEGURAN ÇA

Como já ensinou HeLY LoPes MEIRELLES o juízo competente para o julgamento do mandado de segurança é determinado pela categoria da autoridade coatora e pelo local em essa exerce suas funções.

Já, a definição da competência do juizo para os mandados de segurança impetrados contra atos de autoridades do Estado ou do município depende do que disser a organização judiciária estadual que determinará sempre a comarca, circunscrição ou distrito no qual será feito o julgamento, de acordo com a Constituição e leis aplicáveis. ${ }^{22}$
Essa é a regra geral, vejamos agora alguns casos especiais relativos ao nosso estudo.

3.1 Competência entre comarcas do mesmo Estado

Embora venha prevalecendo o entendimento de que, em mandado de segurança, não se aplica subsidiariamente o Código de Processo Civil, a teor do disposto no art. $20 \mathrm{da} \mathrm{LMS,}{ }^{23}$ a própria Lei n. 1533 51 , em seu art. 19 prevê de forma expressa que o contido no CPC quanto ao litisconsórcio deve ser aplicado aos processos de mandado de segurança.

Por isso, a regra geral da competência quanto à sede funcional, em caso de mandado de segurança com litisconsórcio passivo necessário, dá lugar ao disposto no art. $94, \S 4^{\circ}$ do $\mathrm{CPC}$, que autoriza:

"Havendo dois ou mais réus, com diferentes domicílios, serão demandados no foro de qualquer deles, à escolha do autor."

Assim, sendo o veículo registrado em uma comarca, onde está sediado o delegado do Ciretran local e havendo multas lavradas em outras comarcas, qualquer delas é competente, a escolha do impetrante, para o mandado de segurança que vise ao licenciamento e a decla-

${ }^{21}$ Acórdão unânime da $4^{a}$ Turma do Tribunal Federal de Recursos, de 3 de fevereiro de 1987, na apelação 94.369-SP. Relator o E. Ministro JOSÉ DE JESUS FLHO. RTFR 158/79.

Nesse sentido acórdão unânime da l' Câmara do Tribunal de Justiça do Pará de 30 de abril de 1985, na apelação 10.343. Relator o E. Desembargador OSWALDo PoJUCAM TAVARES. Adcoas 1985, n. 105.137.

22 "Para os mandados de segurança contra atos de autoridades estaduais e munici pais, o juízo competente será sempre o da respectiva comarca, circunscrição ou distrito, segundo a organização judiciária de cada Estado, observados os princípios constitucionais e legais pertinentes." Mandado de Segurança. $19^{\underline{g}}$ Edição. São Paulo: Malheiros, 1998, pág:62).

23 vide $\operatorname{RSTJ} 47 / 85$, maioria 
ração de nulidade das penalidades de trânsito

3.2 Competência entre comarcas de Estados diferentes

Quando se tiver que decidir, no caso sob estudo, entre comarcas de Estados diferentes, é também aplicável o disposto no art. $94, \S$ 4 o, do CPC, vez que, ainda assim, tratam-se de "dois ou mais réus, com domicílios diferentes", inexistindo qualquer óbice à aplicação do dispositivo a órgãos estatais ou a empresas públicas, que prestem serviços de organização e fiscalização de trânsito.

Assim, já se decidiu, por exemplo, que "Aplica-se esta disposição mesmo se zenda Pública. ${ }^{26}$

\subsection{Competência federal}

Sendo qualquer das multas imposta por órgão ou empresa pública ou autarquia federal a competência será deslocada para a Justiça $\mathrm{Fe}$ deral, a teor do que está contido no art. 109, I da Constituição Federal.

Assim já se posicionou o Superior Tribunal de Justiça: ou ambientais. ${ }^{24}$ um dos réus é pessoa jurídica" ${ }^{25}$ ou a $\mathrm{Fa}$ -

"Requerida pelo réu a providência de que trata o parágrafo do art. 47 do CPC, com vista à citaçẫo de entes federais, para integrarem a relação processual como litisconsortes necessários, a compe tência desloca-se para a Justiça Fe deral, a quem cabe pronunciar-se conclusivamente sobre a existência ou não do aventado litisconsórcio necessário ${ }^{27}$ (grifo nosso)

Vencida a etapa da escolha do juízo competente, convém analisar a via adequada.

4. DA VIA JUDICIAL CABÍVEL E DO PEDIDO DE LIMINAR OU ANTECIPAÇÃO DA TUTELA

A via judicial cabível para combater-se esse tipo de ilegalidade pode ser mandado de segurança ou uma ação ordinária, mas aquele só será possível se houver direito líquido e certo demonstrável de pronto com a inicial, enquanto que a ação ordinária deverá ser a via eleita no caso de haver necessidade de produção de provas, além da documental.

Se o que se pretende for somente o reconhecimento da nulidade da multa a ação deverá ser proposta apenas contra a autoridade de trânsito que a aplicou.

24 Em sentido contrário ao nosso pensamento o Tribunal de Justiça do Estado de São Paulo já decidiu que, em caso de impetração contra Superintendente do DER, a competência será de uma das Varas da Fazenda Pública da Capital: "COMPETÊNCIA - Mandado de Segurança - Impetração contra superintendente do DER - Incompetência do Juízo local onde não há Vara Privativa da Fazenda - Competência de uma do Varas da Fazenda da Capi Recurso não conhecido." (Ap. Cível n. 230.385-1 - Jundiaí - 6 Câmara Civil - Rel. Des. OCTAVIO HELENE - 17.08.95 - v.u.). No mesmo sentido: RT 534/112

${ }_{25} S T J-2^{2}$ Seção: RSTJ 7/92, RF 307/100

${ }^{2}$ TFR - $4^{a}$ T., Ag. 43.318SP, rel. Min. CARLOS VELLOSO, j. 25.10.82, deram provimento, v.u., DJU 25.11.82, p. 12.061 .

27 STJ-2ª Seção, CC 14.483-RS, rel. Min. COSTA LEITE, j. 13.09.95, v.u., DJU 9.10.95, p. 33.512, $1^{\text {a }} \mathrm{col}$ em.

Revista da Faculdade de Direito da UFRGS, v. 19, Março/2001
Já, se a pretensão disser respeito apenas ao licenciamento, deve ser parte passiva o delegado que o denega e a autoridade que aplicou a multa, conforme dito acima.

Caso se pretenda a anulação e também o licenciamento, evidentemente, devem ser litisconsortes passivos as duas autoridades.

Tal ação poderá ser um mandado de segurança, se não houver necessidade de dilaçãa probatória e se houver essa necessidade a ação deverá seguir o rito comum.

No mandado de segurança, que depende de prova pré-constituída, o reconhecimento da nulidade das multas é possível e deverá ter como fundamento a falta de elementos de identificação do veículo, de ti picidade da infração de falta de competência quanto à autoridade responsável pela aplicação da multa, bem como inobservância do devido processo legal, que pressupõe a existência de notificação válida assegurando-se ampla defesa e contraditório, conforme ensinamento de ARNALDO RIZZARDO.

Observamos que no caso de falta de no- tificação regular, inclusive quanto ao prazo legal, a autoridade não poderá regularizar posteriormente a situação e cobrar a multa, pois ocorre decadência. ${ }^{20}$ deve-se ressaltar que essa, para ser válida, tem que ser efetiva, não bastando sua mera expedição como dispõe o Código de Trânsito Brasileiro:

“Art. 282 - Aplicada a penalidade, será expedida notificação ao proprietário do veículo ou ao infrator, por remessa postal ou por qualquer outro meio tecnológico hábil, que assegure a ciência da imposição da penalidade.

\& $1^{\circ}$ - A notificação devolvida por desatualização do endereço do proprietário do veículo será considerada válida para todos os efeitos. [...]" ${ }^{30}$ (grifo nosso)

A lei não exige mão-própria, por isso basta que a notificação seja entregue no endereço do infrator para ser considerada válida, 0 mesmo ocorrendo se não houver atualização de endereço pelo proprietário.
Se a alegação for de falta de notificação

28 Comentários ao Código de Trânsito Brasileiro. $2^{a}$ edição. São Paulo: RT, 2000, pág. 729.

Em sentido contrário: LICENCIAMENTO DE VEÍCULO, SEM O PRÉVIO PAGAMENTO DE MULTA - FALTA DE NOTIFICAÇÃO - ADMISSIBILIDADE. O pagamento de multa é exigivel após MULTA - FALTA DE NOTITAÇO - ADMISSIBILIDADE. O pagamento de multa é exigivel após ter havido a devida notheção (Súmula 127, do S. T.J.). NULIDADE DOS AUTOS DE INFRAÇÃO DAS MULTAS - deverá ser objeto de eventual recurso administrativo e, até mesmo, de discussão judicial, incabivel neste estreito campo processual. DÃO PROVIMENTO, EM PARTE, AO REEXAME NECESSÁRIO." (Apelação Civel 107.132-5p-00, relator o E. Desembargador VIANA SANTOS. Tribunal de Justiça do Estado de São Paulo, $4^{g}$ Câmara de Férias - Direito Público. Julgamento realizado no dia 27 de janeiro de 2000)

29 RIZZARDO, Arnaldo. Comentários ao Código de Trânsito Brasileiro. $2^{2}$ edição. São Paulo: RT, 2000, pág. 729.

30 Nesse sentido RIZZARDO, Arnaldo. Op. cit., pág. 717 e 718

Vide ainda Apelação Civel 107.132-50-00, relator o E. Desembargador VIANA SANTOs. Tribunal de Justiça do Estado de São Paulo, $4^{g}$ Câmara de Férias - Direito Público. Julgamento realizado no dia 27 de janeiro de 2000 onde se le "o a tigo $21^{\circ}$, do de Frams - Dito

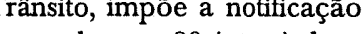
pessoal do infrator, como regra geral, para que apresente defesa ou pague a multa, em 30 (trinta) dias, sem quaisquer acréscimos. Não há comprovação da notificação, assim sendo, a ordem deve ser mantida, tão só; para que se faça o licenciamento do veículo " (grifo nosso) 
A prova de tal entrega deve ser feita por meio do aviso de recebimento do correio ou qualquer outro meio hábil, não bastando meras listas de expedição de notificações.

Para essa prova não basta apenas a notificação que se recebe quando se vai fazer o licenciamento pelo simples fato de que tal notificação sairá sempre com a data de sua emissão, não significando que outra anterior não tenha sido emitida, expedida e efetivamente cumprida.

Caso o interessado pretenda receber uma liminar em mandado de segurança ele deverá desde logo apresentar uma certidão negativa de notificação expedida pela autoridade que aplicou a multa combatida.

Embora se trate de uma prova negativa, ela é relativamente fácil, pois basta um pedido de certidão à autoridade respectiva, direito assegurado constitucionalmente. ${ }^{3 t}$

Podem ocorrer casos em que a multa foi aplicada em local muito distante do local do registro do veículo, nesses casos o juízo pode oficiar determinando o envio da certidão necessária, mas não será cabível a liminar de pronto, só após a chegada da certidão.

Tal possibilidade encontra-se no parágrafo único do art. $6^{\circ} \mathrm{da}$ Lei $1.533 / 51$ :

"No caso em que o documento necessário à prova do alegado se ache em repartição ou estabelecimento público, ou em poder

de autoridade que se recuse fornecê-lo por certidão, o juiz ordenará, preliminarmente, por oficio, a exibição desse documento em original ou em cópia autêntica e marcara para o cumprimento da ordem o prazo de dez dias. [...]"

Se o interessado não quiser ou não puder esperar pela resposta, poderá entrar com ação ordinária pedindo tutela anteci pada e prestando caução, lembrando-se que, embora a prestação de caução não esteja sendo considerada possível no caso de mandado de segurança, ${ }^{32}$ entendemos que ela será cabível caso haja dificuldade de obter-se a certidão, baseando-se o deferimento de prestação de caução no poder geral de cautela do juiz.

Tanto a determinação de apresentação de certidão quanto a notificação de autoridades sediadas em outras comarcas poderão ser feitas pelo correio com recibo de volta, nos termos do art. $9^{\circ}$ e do art. 11 da Lei 1533/51, sendo que esse último permite que tal seja feito ate para atos mais sérios, como é a comunicação da sentença, tratando-se aqui de uma regra especial que derroga a regra geral do art. 222 , " $c$ ", do Código de Processo Civil.

Por fim, quanto ao mérito, cabe à autoridade impetrada provar a legalidade e veracidade do ato de imposição da multa quando houver alegação de falta de notificação, não valendo aí a presunção relativa a esse respeito, porque só a autoridade que impôs a multa tem essa prova. ${ }^{33}$

"Art. $5^{o}$ [...] XXXIV - são a todos assegurados, independentemente do pagamento de taxas: [...] b) obtenção de certidões em repartições públicas, para defesa de direitos e esclarecimento de situaçōes de interesse pessoal; $[\ldots]$

Nesse sentido NEGRÃO, Theotônio. Código de Processo Civil e Legislação Processual em Vigor. 30 edição. São Paulo: Saraiva, 1999, nota 20 ao art. $7^{0}$ da Lei 1.533/51, pág. 1517

Nesse sentido Apelação com revisão no 10558.5-00. Tribunal de Justiça do Estado de São Paulo. Relator o E. Desembargador Brenno Marcondes. Julgamento realizado no dia 09 de dezembro de 1999. No corpo do acórdâo lêse:

"[.../No mérito, depreende-se dos autos que o impetrante não foi devidamente notificado da multa e esta prova cabia unicamente à impetrada produzir (...)" (grifo nosso)

Revista da Faculdade de Direito da UFRGS, v. 19, Março/2001
CONCLUSÕES

De todo o exposto podemos chegar nas seguintes conclusões:

1. o interessado pelo licenciamento, obstado por multas ilegais, poderá pleitear em juízo a realização do mesmo

2. um dos motivos de ilegalidade de negativa de licenciamento pode ser a falta de notificação no prazo legal

3. a autoridade administrativa que tem atribuição para deferir o licenciamento é o delegado de trânsito do município onde se encontra registrado o veículo, também é ela a autoridade que tem poderes para denegá-lo devido à existência de multas, assim, é ela a autoridade coatora no caso

4. o ato que nega o licenciamento só pode ser considerado legal se baseado em multas legais, pois, caso contrário, o vício de ilegalidade das multas o contaminará, pois não há ato legal baseado em ato ilegal

5. a multa e a denegação do licenciamento são atos administrativos autônomos, sendo que a multa produz o efeito jurídico de ensejar o ato de denegação, de onde se conclui que há correlação entre eles

6. como a legalidade ou não da denegação do licenciamento está totalmente relacionada com a legalidade ou não da multa, não é possível julgar-se incabível a denegação do licenciamento sem antes fazer isso com relação à multa, mesmo que apenas incidentalmente

7. no caso de um mandado de segurança, por exemplo, a impetração apenas contra o delegado que nega o licenciamento não é possível, devendo integrar a lide a autoridade que aplicou a multa, pois há á litisconsórcio passivo necessário.

8. quando o ato que se pretende na impetração é o licenciamento, a autoridade com atri- buições para praticá-lo é o delegado responsável pelo trânsito que, assim, é parte legitima também

9. quer o impetrante peça apenas o licenciamento do veículo ou, além dele, também a declaração de nulidade ou insubsistência das multas, a relação jurídicoprocessual exigirá a formação do litisconsórcio passivo, que será, pois, necessário

10. o litisconsórcio em questão é simples e não unitário

11. a falta de notificação de listisconsorte traz como conseqüência a nulidade do processo

12. o juiz deve determinar de pronto a emenda da inicial para regularizar o pólo passivo, devendo fazê-lo pelo menos antes da sentença

13. o juízo competente para o julgamento do mandado de segurança é determinado pela categoria da autoridade coatora e pelo local em que essa exerce suas funções.

14. a definição da competência do juízo para os mandados de segurança impetrados contra atos de autoridades do Estado ou do município depende do que disser a organização judiciária estadual que determinará sempre a comarca, circunscrição ou distrito no qual será feito o julgamento, de acordo com a Constituição e leis aplicáveis

15. sendo o veículo registrado em uma comarca, onde está sediado o delegado do Ciretran local e havendo multas lavradas em outras comarcas, qualquer delas é competente, a escolha do impetrante, para o mandado de segurança que vise ao licenciamento e à declaraçāo de nulidade das penalidades de trânsito ou ambientais

16. quando se tiver que decidir, no caso sob estudo, entre comarcas de Estados diferentes, é também aplicável o disposto no art. $94, \S 4^{\circ}$, do CPC 
17. sendo qualquer das multas imposta por órgão ou empresa pública ou autarquia federal, a competência será deslocada para a Justiça Federal, a teor do que está contido no art. 109, I, da Constituição Federal

18. a via judicial cabível para combater-se esse ti po de ilegalidade pode ser o mandado de segurança ou uma ação ordinária, mas aquele só será possível se houver direito líquido e certo demonstrável de pronto com a inicial, enquanto que a ação ordinária deverá ser a via eleita no caso de haver necessidade de produção de provas, além da documental.

19. no mandado de segurança, que depende de prova pré-constituída, o reconhecimento da nulidade das multas é possível

20. no caso de falta de notificação regular, inclusive quanto ao prazo legal, a autoridade não poderá regularizar posteriormente a situação e cobrar a multa, pois ocorre decadência.

21. a notificação, para ser válida, tem que ser efetiva, não bastando sua mera expedição, embora não se exija mão-própria

22. caso o interessado pretenda receber uma liminar em mandado de segurança ele de verá desde logo apresentar uma certidão negativa de notificação expedida pela autoridade que aplicou a multa combatida

23. em casos excepcionais o juízo pode oficia determinando o envio da certidão necessária, mas não será cabível a liminar de pronto, só após a chegada da certidão

24. se o interessado não quiser ou não puder esperar pela resposta, poderá entrar com ação ordinária pedindo tutela anteci pada e prestando caução

25. a prestação de caução também é possível, excepcionalmente, em alguns casos de mandado de segurança, de acordo com o poder geral de cautela do juiz

26. cabe à autoridade impetrada provar a legalidade e veracidade do ato de imposição da multa quando houver alegação de falta de notificação, não valendo aí a presunção relativa a esse respeito

\title{
Argumentação Jurídica e a Imunidade do Livro Eletrônico
}

\author{
Tumberto Ávila
}

Advogado em Porto Alegre. Prof. da PUC/RS (Grad./Mest.) e da Escola Superior da Magistratura do RGS (AJURIS)

Especialista em Finanças e Mestre em Direito (UFRGS)

Certificado de Estudos em Metodologia e Doutorando em Direito (Universidade de Munique, Alemanha).

"Ob der Satz wahr oder falsch ist, wird durch die Erfahrung entschieden, aber nicht sein Sinn". (A experiência decide se o enunciado é verdadeiro ou falso, mas não o seu sentido).

LUDWIG WTTTGENSTEIN

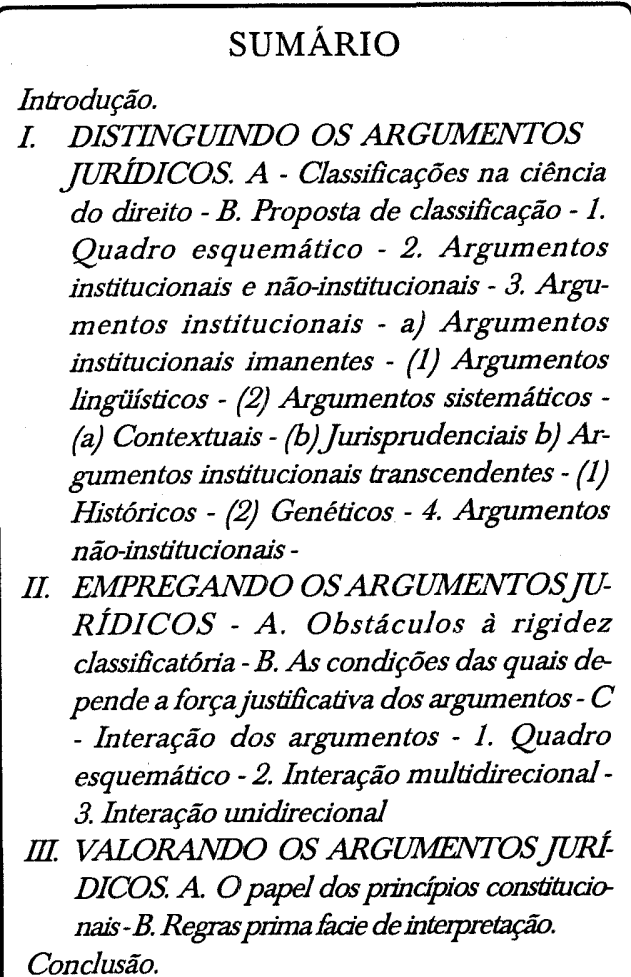

Conclusão.

\section{INTRODUÇÃO}

ara decidir pela imunidade dos "livros eletrônicos", parte da doutrina percorre, das premissas até a conclusão, um processo dedutivo análogo a este: (a) os livros são protegidos pela imunidade; (b) todas as obras que veiculam idéias e são dispostas em seqüência lógica são livros; (c) o chamado "livro eletrônico" consiste numa obra que veicula idéias e é disposta em seqüência lógica; (d) o "livro eletrônico" é um livro; (e) o "livro eletrônico" é protegido pela imunidade dos livros, jornais e periódicos.

Para decidir pelo não-enquadramento dos "livros eletrônicos" no âmbito material da regra de imunidade, outra parte da doutrina percorre, das premissas até a conclusão, um processo dedutivo semelhante ao que segue: (a) os livros são protegidos pela imunidade; (b) todas as obras encadernadas e ordenadas em folhas de papel são livros; (c) o chamado "livro eletrônico" não consiste numa obra encadernada $e$ ordenada em folhas de papel; (d) o "livro ele- 